\title{
The Transformation of Public Economics Research: 1970-2000
}

\section{Citation}

Feldstein, Martin. 2002. The transformation of public economics research: 1970-2000. Journal of public economics 86 , no. 3: 319-326.

\section{Published Version}

http://dx.doi.org/10.1016/S0047-2727(01)00190-6

\section{Permanent link}

http://nrs.harvard.edu/urn-3:HUL.InstRepos:2797442

\section{Terms of Use}

This article was downloaded from Harvard University's DASH repository, and is made available under the terms and conditions applicable to Other Posted Material, as set forth at http:// nrs.harvard.edu/urn-3:HUL.InstRepos:dash.current.terms-of-use\#LAA

\section{Share Your Story}

The Harvard community has made this article openly available.

Please share how this access benefits you. Submit a story.

Accessibility 


\section{The Transformation of Public Economics Research: 1970-2000 \\ Martin Feldstein ${ }^{1}$}

The nature and content of research and teaching in public economics have changed enormously during the past three decades. The field is more theoretically rigorous, more empirical, more focused on real policy issues, and more concerned with government spending as well as with taxation. For me, it has been an exciting time to be a public finance economist and to contribute to this intellectual transformation.

\section{Theoretical Beginnings}

When I began studying public finance as a graduate student in England in the early 1960s, the bible of the field was Richard Musgrave's The Theory of Public Finance (1959). Unlike earlier books by authors like Pigou (1947) which were characterized by prose unencumbered by diagrams and algebra, most of the Musgrave volume looked like a standard price theory book with graphs and algebra showing the partial equilibrium effects of taxes on prices and quantities and the associated effects on deadweight losses. The Musgrave book was about the core issues of incidence and efficiency and the positive effects on the actions of buyers and sellers without the detailed descriptions of tax rules or administrative issues that characterized many earlier public finance books.

Although this text opened up a new era in public finance, its limited mathematics meant that it was weak in dealing with multiproduct problems and in analyzing general equilibrium effects. The general absence of references to econometric research reflected the state of the field at the time. Similarly, although Musgrave discussed general principles of government spending, his classic text did not deal with the specific areas of government spending that would become the subject of much of public economics in the past three decades.

Arnold Harberger's work on the incidence of the corporate income tax (Harberger, 1962) demonstrated the power and importance of simple general equilibrium models. By extending models originally developed to study international trade issues, Harberger showed how elasticities of substitution in production and consumption, factor intensities in production, and consumer preferences all combined to determine the incidence of the corporate tax on labor and capital and on consumers with different preferences. Gone were the earlier vague statements about backward shifting and forward shifting. Although the new general equilibrium models did not give unambiguous answers about corporate tax incidence, we learned the reason for the ambiguity and how various factors like capital mobility would affect incidence.

In two further studies, Harberger $(1964,1966)$ showed how the traditional welfare loss triangle could be extended to multiple taxes on different products and to evaluating the deadweight loss of the corporate income tax. Although multiproduct deadweight loss calculations had been developed earlier by Irving Fisher (1937), and John Hicks (1939), it was Harberger who showed their direct application to excise taxes. Corlett and Hague (1953) made a seminal contribution to the theory of the efficient design of multiproduct excise taxes when some products are nontaxable or are taxed at an arbitrary rate. With these ideas well established, the growing mathematical literacy of the economics profession led to a rediscovery of the Frank Ramsey's 
(1927) theory of optimal excise taxes. Diamond and Mirlees (1971) modernized Ramsey's analysis, showed the optimality of maintaining production efficiency, and derived the conditions that generalized the traditional inverse elasticity rules for optimal taxation.

At about the same time, Mirlees (1971) also developed a formal model of the optimal labor income tax in which the optimal degree of progressivity depends on the government's distributional preferences and on the responsiveness of individuals to the tax schedule. The research provided a formal structure for guiding a benevolent government through the process in which the government optimizes the schedule of income tax rates knowing that the taxpayers will respond by maximizing their own utility subject to the schedule of tax rates. Although the analysis failed to provide any significant general results, it clarified the nature of the optimization problem and provided a framework for deriving results in models with more explicit parametric restrictions.

A further generalization of the original Diamond-Mirlees analysis dealt with designing the optimal combination of income and excise taxes. In the end, that research showed that the optimal tax rules depend on such unobservable properties of the utility function as the separability between leisure and the components of consumption as well as on the higher derivatives of utility as a function of income.

These theoretical developments led to other studies of tax incidence in general equilibrium models (including the important early work on computable general equilibrium analysis by John Shoven and John Whalley ), to extensions of the Diamond-Mirlees optimal tax analysis to include expenditure issues, to new work on the incidence of taxes on corporate source income by David Bradford, Mervyn King, and others, and to my own research on the efficiency effect of taxes on capital income.

These developments in the theory of public finance in the 1960s and 1970s were important in two ways. First, they clarified enormously the profession's thinking about a number of important public finance questions. Although they did not give unambiguous answers, they showed the errors of some earlier views and provided substantial analytic insights. Second, they attracted an outstanding generation of graduate students to the field of public economics. Most of them did not go on to do theoretical research but the improved theoretical foundations in public finance and the new standard of theoretical rigor contributed to their empirical work.

\section{Empirical Research}

The development of empirical work in public economics has, more than anything else, distinguished the research of the past 30 years from all that had gone before. The late 1960s and early 1970s saw for the first time the availability of high speed computers, reliable econometric software, and large machine-readable data sets. These developments, plus the addition of sophisticated econometric techniques to the standard tool kit of graduate students, were all key to the empirical revolution in public economics.

The new data for public finance research included the first public availability of the Current Population Survey, the Federal Reserve's Survey of Consumer Finances, and the Internal Revenue Service public use sample of 100,000 tax returns that became the basic data input for what is now the NBER Taxsim model. For someone like me, recently trained in econometric 
methods, the newly available data provided an exciting opportunity to do a kind of empirical public finance that had not been done before and to confront some of the key questions of public finance in a new and serious empirical way.

An important early subject of empirical research was the study of the effects of taxes on labor supply, or, more accurately, on labor force participation and hours. These studies benefitted also from new econometric techniques for dealing with limited dependent variables and with selfselection bias in estimating behavior from a subset of the population. The results showed important effects of taxes on the participation and hours of women. But the apparent lack of response by men was a warning that an accurate characterization of labor supply must be a much broader measure that includes things like effort, location, acquisition of human capital, and choice of occupation.

More generally, what matters for evaluating the deadweight loss of the distortions induced by labor income taxes is not the change in labor supply alone (even broadly defined) but the change in the individual's taxable income, including the effect on the form of compensation (i.e., on the choice of fringe benefits and working conditions instead of cash) and on the deductions taken by individuals who itemize their tax returns (Feldstein, 1999). Fortunately, unlike the impossibility of studying broadly defined labor supply, it is possible to estimate the effect of changes in marginal tax rates on taxable income using panels of tax data that include repeated observations on the same individuals or, under some conditions, using pooled cross sections of data.

Econometric tax research on the effect of interest income taxes on household saving is difficult because neither the tax return panels nor other panel files give adequate data on saving. Time series data on saving indicates that taxes that reduce the net return on saving do depress saving but these results are subject to a variety of estimation problems. Much more solid evidence on the effects of tax policies on saving have been derived in studies of the effects of IRA and 401-k plans. Although controversy continues, the evidence appears to support the conclusion that these saving incentives do significantly increase overall saving.

A series of legislative changes in the tax treatment of capital gains provided the basis for several studies of the effect of the capital gains tax rate on the selling of corporate stock and the realization of capital gains. Related studies analyzed how tax rates affect the way households allocate their wealth among different types of financial assets. Although results differ among the individual studies, the overall implication is that households do respond to differences in tax rates and to changes in tax rules.

Closely related to these studies of the effect of taxes on financial investment are the studies of the effects of marginal tax rates on home ownership. Because mortgage interest payments are deductible in calculating taxable income while the imputed value of housing services is not included in taxable income, individuals with high marginal tax rates have a strong incentive to own a home and to increase their investment in owner-occupied housing when tax rates rise. Several econometric studies confirm that both inferences are correct, estimate the magnitude of the distortion, and calculate the resulting efficiency losses.

Other empirical studies of the effects of taxation deal with such things as charitable giving and the demand for health insurance. There is, in short, no aspect of household tax-related behavior that has not been studied. But with new tax policies and improved data sets, there will be new 
opportunities in the future to improve and refine our empirical knowledge in a wide range of areas.

In addition to these empirical studies, there have also been analytic studies of taxation that sharpened our understanding of the effect of taxes on risk taking by individuals, of how taxes affect the financial policy of corporations, and of the implications of analyzing tax issues in the context of a growing economy.

\section{Government Spending}

A second major aspect of the transformation of research in public finance since the 1960s has been to broaden the subject to include government spending as well as taxation. This shift in focus was no doubt stimulated by the enormous expansion of government spending. In the United States, non-defense spending of the federal government rose from less than 10 percent of GDP in 1965 to more than 15 percent in 2000, reflecting a wide array of new programs ranging from pre-school education to health care for the aged. Economists responded to the challenge of studying these new programs. The field of public finance was thus transformed from the study of the taxes used to finance basic government services to the field of public economics that looked also at the effect of government spending on a wide range of programs.

Much of the growth of government spending has been for social insurance programs and the research in public economics has matched that emphasis. Social Security pensions, unemployment insurance, workers' compensation, and the Medicare/Medicaid programs of health care for the aged and the poor raised new theoretical as well as empirical issues that became a major focus for research.

Social insurance programs were attractive research subjects not only because they are the largest part of government spending but also because they have many analytic similarities to taxation. The analyses of public spending programs study not only the extent to which they achieve their stated purposes but also the incidence and excess burden of each program. The design of social insurance programs involves tradeoffs between protection and distortion that are analogous to the tradeoffs between distribution and efficiency considerations in taxation.

The Social Security program of benefits to retirees, dependents and the disabled is the largest form of government spending. Empirical studies have shown that Social Security reduces saving and induces early retirement in the United States and other countries. In addition to these studies of the behavioral effects of Social Security, there have been a variety of empirical studies of the general equilibrium effects of Social Security and Social Security reform, including the effects of shifting from the current pay-as-you-go system to systems that rely in whole or in part on investment-based accounts. Separately, analytic studies have examined the optimal design of social security retirement and disability programs.

Studies of other social insurance programs, including disability insurance and worker's compensation, also estimated behavioral effects, analyzing the distortions to incentives and the efficacy of the programs in providing the protection for which they are intended.

Government health care programs are important fiscally as well as socially. Even in the United States, the government accounts for nearly half of total health care spending and exceeds six percent of GDP. The large volume of microeconomic data about the cost and provision of health 
care services also encouraged the growth of research in this area. The introduction of changes in the state level Medicaid program at different times in different states provided a source of identification for studying different aspects of this significant program.

While early work on the economics of education focused on measuring and explaining the returns to human capital accumulation, the public finance research on education has looked at issues like the effect of alternative local tax and grant rules on the level and distribution of local government education spending. Important also have been the Tiebout-inspired analyses of the effects of competition in education on various educational outcomes. The government's increased role in providing scholarships for higher education has also induced public finance economists to study the impact of such spending on college enrollment and graduation as well as on household saving.

Other government programs ranging from child care to the criminal justice system have been the subject of public finance studies that compare the cost of achieving program goals to the full cost of the taxes needed to finance that spending, including the deadweight loss associated with that tax revenue.

\section{$\underline{\text { Macroeconomic Issues }}$}

Although Keynesian fiscal policy was a major focus of Richard Musgrave's The Theory of Public Finance, by the 1970 s the analysis of stabilization policies had largely shifted to the field of macroeconomics where the emphasis was much more on monetary policy than on variations in fiscal stimulus through changes in budget deficits and surpluses. Public finance research nevertheless contributed to the debate by studying how tax rules like the investment tax credit and depreciation allowances could be used to stimulate business investment in a counter-cyclical way.

The major social insurance programs also lie on the border between macroeconomics and public finance. Unemployment insurance raises the level of unemployment and contributes to its cyclical volatility. Public finance researchers have crossed the border into macroeconomics and labor economics to study the effect of unemployment insurance on the level and character of unemployment and to analyze ways in which unemployment insurance can be improved to reduce the inefficient labor market distortions without decreasing protection against the hardships of unemployment. Social Security pensions can also have an important macroeconomic effect by changing the rate of capital accumulation and therefore the rate of economic growth.

The high inflation rate in the late 1970s inspired research on how the interaction of inflation and tax rules affects the level and distribution of saving and investment. This research showed that the neutrality of money and money growth in theoretical macroeconomic models does not hold in actual economies that tax nominal capital income. The analysis also led to calculations showing that the substantial deadweight loss of even moderate rates of inflation.

\section{$\underline{\text { Fiscal Federalism }}$}

The complex federal structure of the U.S. government assigns important decision-making authority to state and local governments. Those state and local governments are now responsible for spending an amount equal to more than 60 percent of the spending by the federal 
government. An important area of public economics research has been the analysis of how those governments choose their tax and spending policies, how those choices are affected by the policies of higher levels of government (including block grants and matching grants), and how the resulting inter-area differences in taxes and spending affect the behavior of the private sector and the outcomes of government programs. Although such work has dealt primarily with the United States, it is likely to become more important as the European Union evolves toward a more federal fiscal structure.

\section{Looking Ahead}

The past three decades have been an enormously productive period for the field of public economics with important advances in theoretical analysis and empirical knowledge. The central role of the government in the economy and the associated high marginal tax rates mean that the problems of taxing and spending will continue to provide challenging opportunities for research in public economics. If those studies are to be useful in improving public policy, they must continue to speak to the real problems of the economy and must combine appropriate analytic models with sound empirical research.

Cambridge, MA

September 2001

\section{References}

Atkinson, A.B. and J.E. Stiglitz (1980), Lectures on Public Economics, McGraw-Hill, New York.

Bradford, D.F. (1981), "The Incidence and Allocation Effects of a Tax on Corporation Distributions, Journal of Public Economics, XV, 1-22.

Corlett, W.J. and D.C. Hague (1953), "Complementarity and the excess burden of taxation", Review of Economic Studies, 21, 21-30.

Dixit, A.K. and J.J. Munk (1977), "Welfare effects of tax and price changes: a correction", Journal of Public Economics, 8, 103-107.

Feldstein, M. (1978), "The Welfare Cost of Capital Income Taxation," Journal of Political Economy, 86,

Feldstein, M. (1999), "Tax Avoidance and the Deadweight Loss of the Income Tax, Review of Economics and Statistics, November 1999, 81(4), 674-680.

Fisher, I. (1937), "Income in theory and income taxation practice", Econometrica, 5, 1-55.

Harberger, A.C. (1962), "The incidence of the corporation income tax", Journal of Political Economy, 70, 215-250.

Harberger, A.C. (1964), "Taxation, resource allocation, and welfare" in The Role of Direct and Indirect Taxes in the Federal Revenue System, J. Due (ed.), Princeton University Press, Princeton, New Jersey. 
Harberger, A.C. (1966), "Efficiency Effects of Taxes on Income from Capital," in M. Krzyaniak, ed. Effects of Corporate Income Taxes, Wayne State University Press, Detroit.

Hicks, J.R. (1939), Value and Capital, Oxford University Press, London.

King, M.A. (1977), Public Policy and the Corporation, Chapman and Hall, London.

Mirrlees, J.A. (1971), "An exploration in the theory of optimum income taxation", Review of Economic Studies, 38, 175-208.

Musgrave, R.A. (1959), The Theory of Public Finance, McGraw-Hill, New York.

Pigou, A.C. (1947), A Study in Public Finance, (3rd edn.), Macmillan, London.

Ramsey, F.P. (1927), "A contribution to the theory of taxation", Economic Journal, 37, 47-61.

Shoven, J.B. and J. Whalley (1972), "A general equilibrium calculation of the effects of differential taxation income from capital in the U.S.", Journal of Public Economics, 1, 281-321.

${ }^{1}$ Professor of Economics, Harvard University and President of the National Bureau of Economic Research. This essay, written for the 30th Anniversary of the Journal of Public Economics, focuses on research that has been described in the English language and therefore primarily on work done in the United States and Britain. The Journal played an important role in the transformation described here. I am grateful for the opportunity to serve as a Co-Editor of the Journal from 1972 through 1986, as an associate editor from 1987 through 1997, and as an an Advisory Editor since that time. 